true of the scientific worker in industry as of his colleague in a university. The same process of organic growth can be found in both places-and, what Prof. Polanyi overlooks, the same narrow specialization, hampering scientific advance and creative work. $\mathrm{He}$ does indeed admit that public interest can influence broadly the lines of scientific investigation, but he passes over the value of the reciprocal influence on both science and society of accurate and forceful scientific exposition, as well as the extent to which the resources already at the disposal of science are determined by the nature of the society in which the man of science lives and its outlook on world affairs. Prof. Polanyi is accordingly largely 'tilting at windmills' in his attack on the idea of central planning. He offers no alternative to the present chaos into which the absence of plans has led us, and ignores the contribution which skilful exposition might make to the engendering of a scientific outlook in society as a whole. Much of the value of his address is lost through its attack on those who are every bit as determined as he is to defend the integrity of scientific thought and method, but who would seek to extend the realm into which that method and outlook are brought to play. Leadership, as he observes, can be retained only by those who can point the way toward the future; but Prof. Polanyi fails to do so or to see the real meaning of his own description of the stream of thought ever widening through the centuries, following steadily the purpose set by the tradition of science and its view of the purpose and true greatness of human society.

\section{Manufacture of Magnesium}

IT is common knowledge that sea-water contains common salt and small quantities of other substances and even traces of rarer elements such as gold. Throughout the ages, in warm countries, a crude sale has been made by the evaporation of brine ponds with the heat of the sun, but only recently has the sea become a commercial source of two other constituents, bromine and magnesium, for which the industrial demand has grown to be considerable. The demand for bromine arose as the result of the discovery of the value of 'Ethyl' as an antiknock agent to be used with petrol : its manufacture and use has grown to a point where very large quantities of bromine are necessary. The problem was solved when the Dow Chemical Company in the United States established an elaborate process, which is largely automatic and continuous in its operation, for dealing with immense quantities of sea-water. The bromine is driven out of the water by a slight excess of chlorine and ultimately isolated. The solution is one of the triumphs of modern chemical engineering.

There is now a demand for magnesium, lightest of the structural metals. Sea-water contains $0 \cdot 1$ per cent of mägnesium, which is separated as the insoluble hydroxide by reaction with lime produced from nearby beds of oyster shell and afterwards converted into chloride, from which the metal is finally made by electrolysis. The quantity of water treated is so large that it cannot be put back into the sea at the intake point, but must be taken by canal several miles down the coast so as to prevent dilution of the incoming water. An output of 15,000 tons of metal per annum is aimed at. The need for magnesium in quantity has become so urgent that several plants for the purpose are being erected in the United States. Some of these are based on an electro-thermal process involving the reduction of a suitable magnesium ore. The metal has such a high affinity for oxygen that at intermediate temperatures it is able to take this away from carbon oxides; to prevent this happening, the mixture has to be shock-cooled with large volumes of hydrogen. The process is a daring one, and various production difficulties are likely to be encountered; the fact that it is being undertaken shows the high level to which modern chemical and metallurgical engineering has attained. In this instance ore and electrical power are cheap ; it is the process which presents difficulties.

\section{Learning and Physique}

OF one hundred and fifty members of the U.S. National Academy of Sciences examined by Dr. Ales Hrdlicka, there were "no true reds" (Mem. Nat. Acad. Sci., 23, Third Mem.: Observations on the Members of the National Academy of Sciences. Washington: Government Publications Office. 30 cents). Moreover, there were no "pronounced blonds". Apparently, the members of the Academy were significantly darker in hair coloration than were the typical "Old Americans" previously examined by Hrdlicka. The mean age of those upon whom the investigation was carried out was 59.57 years, which is very nearly the mean age of the total membership of the Academy. The hundred and fifty members were taller and heavier than the general run of the Old Americans. They had larger and broader heads and deeper chests than the more cultured classes of the Old Americans who are not members. Hrdlička's summary of the characters of members of the Academy is that: "They obviously present, in general, an above-the-average selection of men both as to nature and nurture. . . . They are furthermore a remarkably normal group, of evidently good heredity and good ontogenetic history". Contrary to the popular conception of what a 'professor' should be, there were no "physically abnormal geniuses in the lot", and all had good eyesight, despite the fact that many wore glasses for reading.

Perhaps most people in picturing the collective membership of any learned society would be inclined to include a very definite admixture of freaks. Such a picture of the members of the National Academy of Sciences would obviously be incorrect. Would it be incorrect for the membership of the Royal Society? Are the members of the learned societies of all countries men of above the average of physical wellbeing ? Perhaps, after all, the old maxim of "mens sana in corpore sano" is correct, and the stage professor no more represents a reality than does the stage American. 